\title{
Role of Value Added Tax in Total Tax Revenue: An Empirical Study of Nepal
}

\author{
Ananta Raj Dahal (Ph. D. Scholar)*
}

\begin{abstract}
This paper examines the role of Value Added Tax (VAT) in total tax of Nepal. Tax is the main sources of government revenue. There are different kinds of tax systems used in the world. The concept of VAT had been introduced in 1919 A D from Germany as a new concept of indirect tax system of the world. VAT system have introduced from 1995 A D in Nepal. The specific objectives are to analyse the trend of VAT and to examine the correlation between VAT with total revenue and total tax revenue in Nepal. This study is based on secondary data, which are incorporated from the Ministry of Finance and other related government as well as non-government organizations. Both analytical and descriptive statistics are applied as methods in this study. At the process of data analysis some statistical tools like regression, correlation, etc. are used. The study shows that VAT has significant percentage in total revenue and total tax revenue in Nepal. There are more than 99 present variations due to VAT in total revenue, total tax revenue and indirect tax revenue. All these relationship are significant as $r>6$ PEr everywhere. Thus, VAT has significant contribution in government revenue of Nepal. But the system of VAT must be improved to increase its effectiveness through the government policy level and increase awareness tax payers about baling system of VAT.
\end{abstract}

Key words: Tax, revenue, capital formation, value added tax $\&$ statistical analysis.

\section{Introduction}

One of the most important issues faced by the developing countries which are raised even more seriously today is finding ways to improve the internal mobilization of domestic resources in order to finance public expenditure. In the context of degradation of public finances in the developed world, the high dependency of developing countries on external development assistance should be addressed and reversed by acting on the ways to efficiently increase the mobilization of domestic resources. Looking at the ways to improve the mobilization of domestic resources and to build fiscal space in these

*Mr. Dahal is a Lecturer at the Department of Economics, Patan Multiple Campus, TU, Lalitpur, Nepal. Email:anantadahal38@yahoo.com 
countries, it is therefore crucial for the sustainability of public finances and for economic development in general.

The role of revenue in the development of a country is not less important than the role of oxygen for the existence of human body. In this context, a government needs to mobilize a lot of internal resources has to fulfil its responsibility towards nation and people. In the developing country like Nepal, there is necessity for raising a larger volume of funds for the development and administration expenses.

The revenue collection is a challenging task in itself which demands increasing necessity of regular expenditure in general and development expenditure in particular. Development expenditure has been dependent almost entirely on the foreign aid, so external assistance is uncertain, precarious, inconvenient and not conducive to the healthy and overall development. The foreign aids are not bad for economic development of the nation. But the experience of the most of the developing countries shows that there are negative effects of increasing international grants and loans to finance for the public development activities if foreign loans and grants are used in unproductive sector.

Commonly, there are two types of tax: direct and indirect. Direct tax is directly imposed on a person or organizations which are income tax, property tax etc. Indirect tax is indirectly imposed on a person or an organization which is excise duty, custom duties, sales tax, entertainment tax and value added tax (VAT) etc. These taxes are shifted to other people.

VAT is the most recent innovation in the field of taxation. It is levied on the value added of goods and services. VAT is an improved version of sales tax. It is levied at different stages of production and distribution. It is a multistage tax. This is connected at the different stage of production and distribution of goods and services. Existence of VAT concept was seen in 1919 A.D. German industrialist Wilhem Van Slemens proposed the tax to replace multistage sales taxes but at that time Germany did not apply VAT, but it reduced the rate of multistage sales tax. Shoup (1969) explained Value Added Tax as the latest and probably the final stage in a historical development of general sales tax, imposed on the value added by business firms, which is based on goods and services.

Due (1977) analyzed that among the indirect taxes, VAT is the best one as the latest form of sales tax. Its usage has expanded rapidly because of broader coverage. Agha and Haughton (1996) have made an effort to assess the VAT in Taiwan. According to them, the VAT in Taiwan was implemented in order to increase the competitiveness on exports and the efficiency of business tax structure. Yoo (2000) examines and evaluates "Value Added Tax (VAT) in the Republic of Korea". He concluded that VAT has broadened tax 
base, reduced evasion, increased revenue as well as solved many problems. Goode (1986) in the book "Government finance in Developing Countries" described VAT as the most important tax innovation of the second half of the 20th century. Ebeke (2010) investigates in particular whether the presence of a value added tax (VAT) system increases the benefit of the inflows of remittances in terms of high and less volatile tax revenue ratio.

\section{In the Context of Nepal}

In the Nepalese context, the tax system review tax force was constituted by Nepalese government in 1995 to propose and recommend implementing VAT. In place of sales tax, hotel tax and entertainment tax, Nepalese government implemented it in 16 November 1997. However, VAT came into full operation in February 1998 (Khadka, 2001).

Nepal is also a developing country situated between two economically rising nations India and China. Rapid population growth, increasing unemployment, resource constraint and high dependency in agriculture, low living standard and poor infrastructure etc. are the common features of Nepalese economy. To solve these problems, it needs more revenue obtained though the effective mobilization of domestic resources. But Nepalese resource mobilization is still poor that does not cover the growing expenditure. Government expenditure is increasing every year but revenue is not growing equivalently as per the expenditure. In addition, the country is also facing the increasing burden of foreign loans. In order to increase revenue, different sources are available but they have their own merits and demerits. That's why government should try to mobilize resources through such measure which has less trouble and more benefits.

Tax system of Nepal is still dominated by custom duties but Nepal has entered as the member of World Tread Organization (WTO). Being the member of WTO, the government should reduce the custom duties drastically within certain time period. So it is expected that VAT would be a major instrument to avoid deficit financing. It is the best form of sales tax within most merits of self-pricing, catch up effect, broad base etc. So there is no alternative option available except increasing effectiveness of it to mobilize internal resource effectively. Thus, VAT can be the optimal solution of resources gap and high dependency of foreign aid.

However, the problem of VAT in Nepal is still a matter of discussion. Mainly, the businessmen are reluctant to pay VAT, even the consumers are not aware of taking VAT invoice. Low voluntary tax compliance, cumbersome, legal and administrative procedures, weak tax administration and tax evasion are still prevailing. Khadka (2001) explores in a report that VAT is the most recent innovation in the field of taxation. Dahal (1995) 'Task 
Force' recommends VAT in the place of the existing sales tax and small service base taxes as a long term tax reform measure. Khanal (2008) explained that Value Added Tax puts greater significance in revenue mobilization in Nepal. In his conclusion the share of direct tax and indirect tax are around 30 percent and 70 percent of total tax revenue respectively.

\section{Objectives}

The main objective of this study is to assess the contributions of value added tax in Nepal. The specific objectives of this study are to analyze the trends of Value Added Tax (VAT) and to examine the correlation between VAT with total revenue and total tax revenue in Nepal.

\section{Data and Methodology}

This study is based on secondary data. The data are collected from Ministry of Finance, Tax Department; other related government offices of Nepal and Economic Survey of different fiscal years. Both analytical and descriptive statistics are applied as methods in this study. At the process of data analysis some statistical tools like regression, correlation, etc. are used.

\section{Trends and Correlation Analysis of Vat}

The analysis with the help of statistical tool is performed taking 18 years' data are being used for trend analysis of Vat and taking 26 years' data are used for coefficient of correlation analysis between Vat with tax revenue and total revenue.

\section{Trend Analysis}

This analysis depends on the basis of 18 years of data. The revenue amount of VAT from domestic product and import has been predicted as.

Let the trend line be, $\mathrm{Y}_{\mathrm{c}}=\mathrm{a}+\mathrm{bx}$

Where,

$\mathrm{Y}_{\mathrm{c}}=$ total amount of domestic product/ import product of VAT

$\mathrm{a}=$ constant which is computed $\mathrm{y}$ value when $\mathrm{x}=0$

$\mathrm{b}=$ constant which is change in $\mathrm{y}$ corresponding to the change in $\mathrm{x}$ by one unit.

$\mathrm{X}=$ time in the case of time series analysis.

Formula to be used:-

$$
a=\frac{\sum y}{n} \quad \& \quad b=\frac{\sum x y}{\sum y^{2}}
$$


Here, in case of this study, each domestic VAT and import VAT at a time is considered as the main variable and denoted by $(y, x)$ is ' $t$ ' base year, here all the years are denoted by t. the following table shows the trend values of domestic product VAT and import VAT from FY 1999/2000 to 2016/17.

Table-1: Trends of domestic product VAT and import VAT (Rs in Billions)

\begin{tabular}{|l|c|c|}
\hline Years $(\mathrm{t})$ & $\begin{array}{c}\mathrm{Y}_{\mathrm{c}}=\mathrm{a}+\mathrm{bx}(\text { trend value of domestic } \\
\text { product VAT) }\end{array}$ & $\mathrm{Y}_{\mathrm{c}}=\mathbf{a}+\mathbf{b x}$ (trend value of import VAT) \\
\hline $1999 / 2000$ & -6.7721 & -12.3545 \\
\hline $2000 / 01$ & -3.4732 & -6.4303 \\
\hline $2001 / 02$ & -0.1743 & -0.5061 \\
\hline $2002 / 03$ & 3.1246 & 5.4181 \\
\hline $2003 / 04$ & 6.4235 & 11.3423 \\
\hline $2004 / 05$ & 9.7224 & 17.2665 \\
\hline $2005 / 06$ & 13.0213 & 23.1907 \\
\hline $2006 / 07$ & 16.3202 & 29.1149 \\
\hline $2007 / 08$ & 19.6191 & 35.0391 \\
\hline $2008 / 09$ & 22.9180 & 40.9633 \\
\hline $2009 / 10$ & 26.2169 & 46.8875 \\
\hline $2010 / 11$ & 29.5158 & 52.8117 \\
\hline $2011 / 12$ & 32.8147 & 58.7359 \\
\hline $2012 / 13$ & 36.1136 & 64.6601 \\
\hline $2013 / 14$ & 39.4125 & 70.5843 \\
\hline $2014 / 15$ & 42.7114 & 76.5085 \\
\hline $2015 / 16$ & 46.0103 & 82.4327 \\
\hline $2016 / 17$ & 49.3092 & 88.3569 \\
\hline
\end{tabular}

Source: Appendix 1\& 2

Therefore, by the help of trend analysis we find the value of domestic product VAT and import VAT for past 18 years. By adopting same formula of trend we can get the future trend value of domestic product and import product VAT which will reflect the trends in composition of VAT. 


\section{Correlation Analysis}

\section{a. Correlation between Vat and Total Revenue}

The coefficient of correlation ' $r$ ' between VAT and total revenue measures the degree and relationship between these two variables. The purpose of computing coefficient of correlation between VAT and total revenue is to find out whether VAT is significantly contributed in total revenue or not.

To find out the Karl Pearson's correlation ' $r$ ' between VAT and total revenue, VAT(y) is assumed to be independent variable and total revenue ( $\mathrm{x}$ ) is assumed to dependent variable. The assumption is made that the total revenue will decrease or increase, as VAT decreases or increases. The correlation between VAT and total revenue is shown in the appendix no 3 . The value of $r$ is calculated in between -1 to +1 . The negative value of $r$ signifies the opposite relationship between the variable i.e. increases in VAT will lead decrease in total revenue and vice-versa. While positive value of $r$ shows the positive relationship between variables. The value of $r, r^{2}$ and $6 \mathrm{PEr}$ between VAT and total revenue is given below:

$\mathrm{r}=0.9980, \mathrm{r}^{2}=0.9961, \mathrm{PEr}=0.000518,6 \mathrm{PEr}=0.0031$, (Source: Appendix 3)

From the above, it is found that the coefficient of correlation ' $r$ ' between VAT and total revenue is 0.9980 . This shows the highly positive relationship between VAT and total revenue. The value of coefficient determination $r^{2}=0.9961$. It means that there will be the variation in total revenue 99.61 percent due to VAT and remaining percent by another factor, moreover higher than probable error (6PEr). Therefore the value of $r$ is significant. It can be concluded that there is significant relationship between VAT and total revenue. So, VAT has contributed a significant amount in total revenue of Nepal.

\section{b. Correlation between Vat and Total Tax Revenue}

To identify the impact and contribution of VAT in total tax revenue, correlation between these two variables should be calculated. To find out the Karl Pearson's coefficient of correlation ' $r$ ' between VAT and total tax revenue, VAT(y) is assumed as independent variable and total tax revenue (x) is taken as a dependent variable. The correlation between VAT and total tax revenue is shown in appendix no. 4. The value of $r$ is calculated between +1 to- 1 . The negative value of $r$ signifies the opposite relationship between the variables and vice-versa.

$\mathrm{r}=0.9974, \mathrm{r}^{2}=0.9949, \mathrm{PEr}=0.000672,6 \mathrm{PEr}=0.004032$, (Source: Appendix 4) 
Here, the coefficient of correlation between VAT and total tax revenue is 0.9974 . It seems to be near +1 . This shows that there is highly positive relationship between VAT and total tax revenue. The value of coefficient determination $\left(\mathrm{r}^{2}\right)$ is equal to 0.9949 which implies that there will be variation in total revenue 99.49 percent due to VAT and remaining 0.51 percent by other factor. Similarly ' $r$ ' is far higher than 6PEr. So that it can be concluded that the value of ' $r$ ' is significant. VAT has effective contribution on total tax revenue.

\section{Conclusion}

Through the analysis of time series data of 18 years, we can conclude that there would be higher potentiality in VAT revenue in Nepal. So the government must give higher attention in VAT for effective resource mobilization. After analyzing the coefficient of correlation between VAT and total revenue, total tax revenue and total indirect tax revenue, we can conclude that VAT has contributed a significant percentage in total revenue, total tax revenue and indirect tax revenue because they have higher positive relationship. Similarly, there is more than 99 percent variation due to VAT in total revenue, total tax revenue and indirect tax revenue. And all these relationship are significant as $\mathrm{r}>6 \mathrm{PEr}$ everywhere. Thus, VAT has significant contribution in government revenue of Nepal. Moreover, the contribution of VAT, in total revenue is not up to the satisfactory level. It could contribute just about 27.33 percent to the total revenue and 30.40 percent to the tax revenue of Nepal in the fiscal year (1991/92 to 2016/17).

From the overall discussion it is concluded that the VAT is the effective system for the revenue collection of the country. However it has to necessary to improve some policy of VAT system and increase awareness for the taxpayers about VAT system. Government has to establish the effective monetary system to correct the contribution of the VAT in total revenue and tax revenue in Nepal.

\section{References}

Agha, A., \& Haughton, J. (1996). Designing vat systems: Some efficiency considerations. Review of Economics and Statistics, 78 (2), 100-115, Cambridge, United States.

Dahal, M. K. (1995). Tax system review task forces report. Kathmandu: Ministry of Finance, His Majesty's Government of Nepal, Singh Durbar, Nepal.

Due, J. F. (1977). VAT in developing economics, taxation and development, N. T. Wage Ed. New York: Praeger Publisher Inc., United States

Ebeke, C. H. (2010). Remittances, value added tax and tax revenue in developing countries, Working Paper, CERDI, Clermont University. 
Goode, R. (1986). Government finance in developing countries, New Delhi: MaGra Hill Ltd., India.

Kandel, P. R. (2008). Tax laws and tax planning in Nepal: Based on income tax act, 2058 and value added tax act, 2052. Kathmandu: Buddha Academic Publishers \& Distributors, Nepal.

Khadka, R. B. (2001). Vat: Four years of implication. Kathmandu: Revenue Department, Ministry of Finance, Nepal.

Ministry of Finance (MoF). (1992 to 2017). Economic survey. Kathmandu: Ministry of Finance, Singh Durbar, Nepal .

Ministry of Finance (MoF). (1992 to 2017). Budget Speech. Kathmandu: Ministry of Finance, Singh Durbar, Nepal .

Musgrave, R. A., \& Musgrave, P. B. (1976). Public finance in theory and practice. Kathmandu: Tara, Publishing House, Nepal.

Shop, C. S. (1969). Public Finance. London: Widenfeld and Nicolson Ltd, U. K.

Tait, A. A. (1991). Value-added tax: Administrative and policy issues. Washington DC: International Monetary Fund, United States.

Yoo, I. (2000). Experience with tax reform in the Republic of Korea. Seoul: Asia-Pacific Development Journal, 7 (2), 150-166, South Korea. 


\section{Appendices}

\section{Appendix-i}

\section{Trend value of domestic product VAT 1999/2000 to 2016/17( In Rs Billions)}

\begin{tabular}{|l|c|c|c|c|c|}
\hline \multicolumn{1}{|c|}{ FY $(\mathrm{t})$} & Domestic products $(\mathrm{y})$ & $\mathrm{x}=\mathrm{t}-2008$ & $\mathrm{x}^{2}$ & $\mathrm{Xy}$ & $\mathrm{Y}=\mathrm{a}+\mathrm{bx}$ \\
\hline $1999 / 00$ & 3.73 & -8 & 64 & -29.8000 & -6.7721 \\
\hline $2000 / 01$ & 4.74 & -7 & 49 & -33.2080 & -3.4732 \\
\hline $2001 / 02$ & 4.61 & -6 & 36 & -27.6540 & -0.1743 \\
\hline $2002 / 03$ & 4.83 & -5 & 25 & -24.1550 & 3.1246 \\
\hline $2003 / 04$ & 5.60 & -4 & 16 & -22.4160 & 6.4235 \\
\hline $2004 / 05$ & 6.61 & -3 & 9 & -19.8420 & 9.7224 \\
\hline $2005 / 06$ & 8.15 & -2 & 4 & -16.3000 & 13.0213 \\
\hline $2006 / 07$ & 9.63 & -1 & 1 & -9.6310 & 16.3202 \\
\hline $2007 / 08$ & 10.81 & 0 & 0 & 0.0000 & 19.6191 \\
\hline $2008 / 09$ & 13.92 & 1 & 1 & 13.9180 & 22.9180 \\
\hline $2009 / 10$ & 19.12 & 2 & 4 & 38.2400 & 26.2169 \\
\hline $2010 / 11$ & 22.36 & 3 & 9 & 67.0800 & 29.5158 \\
\hline $2011 / 12$ & 25.65 & 4 & 16 & 102.6000 & 32.8147 \\
\hline $2012 / 13$ & 28.49 & 5 & 25 & 142.4500 & 36.1136 \\
\hline $2013 / 14$ & 34.39 & 6 & 36 & 206.3400 & 39.4125 \\
\hline $2014 / 15$ & 39.56 & 7 & 49 & 276.9200 & 42.7114 \\
\hline $2015 / 16$ & 49.82 & 8 & 64 & 398.5600 & 46.0103 \\
\hline $2016 / 17$ & 61.12 & 9 & 81 & 550.0800 & 49.3092 \\
\hline & $\sum \mathrm{y}=353.14$ & $\sum \mathrm{x}^{2}=489$ & $\sum \mathrm{xy}=1613.1820$ & \\
\hline
\end{tabular}

Source: Economic Survey, 1999/00 to 2016/17

Here, the trend line is supposed to be:

$\mathrm{Y}_{\mathrm{c}}=\mathrm{a}+\mathrm{bx}$

Where, $\mathrm{y}=$ dependent variables $\mathrm{x}=$ derivation from sources convenient time periods.

$\mathrm{b}=$ slope of trend line $\mathrm{a}=\mathrm{y}$ - intercept

$=\frac{353.14}{18}=19.6191 a=\frac{\sum y}{n} \quad b=\frac{\sum x y}{\sum x^{2}}=\frac{1613.1820}{489}=3.2989$ 


\section{Appendix-ii}

\section{Trend value of import VAT 1999/2000 to 2016/17(In Rs Billions)}

\begin{tabular}{|c|c|c|c|c|c|}
\hline $\mathrm{Y}(\mathrm{t})$ & Import $(\mathrm{y})$ & $\mathrm{x}=\mathrm{t}-2008$ & $\mathrm{x}^{2}$ & $\mathrm{Xy}$ & $\mathrm{Y}=\mathrm{a}+\mathrm{bx}$ \\
\hline $1999 / 00$ & 6.13 & -8 & 64 & -49.0320 & -12.3545 \\
\hline $2000 / 01$ & 7.30 & -7 & 49 & -51.1210 & -6.4303 \\
\hline $2001 / 02$ & 7.35 & -6 & 36 & -44.1240 & -0.5061 \\
\hline $2002 / 03$ & 8.63 & -5 & 25 & -43.1400 & 5.4181 \\
\hline $2003 / 04$ & 8.87 & -4 & 16 & -35.4960 & 11.3423 \\
\hline $2004 / 05$ & 12.27 & -3 & 9 & -36.8100 & 17.2665 \\
\hline $2005 / 06$ & 13.46 & -2 & 4 & -26.9240 & 23.1907 \\
\hline $2006 / 07$ & 16.46 & -1 & 1 & -16.4640 & 29.1149 \\
\hline $2007 / 08$ & 19.01 & 0 & 0 & 0.0000 & 35.0391 \\
\hline $2008 / 09$ & 25.78 & 1 & 1 & 25.7820 & 40.9633 \\
\hline $2009 / 10$ & 35.80 & 2 & 4 & 71.6000 & 46.8875 \\
\hline $2010 / 11$ & 39.30 & 3 & 9 & 117.9000 & 52.8117 \\
\hline $2011 / 12$ & 46.53 & 4 & 16 & 186.1200 & 58.7359 \\
\hline $2012 / 13$ & 55.01 & 5 & 25 & 275.0500 & 64.6601 \\
\hline $2013 / 14$ & 66.57 & 6 & 36 & 399.4200 & 70.5843 \\
\hline $2014 / 15$ & 78.94 & 7 & 49 & 552.5800 & 76.5085 \\
\hline $2015 / 16$ & 77.94 & 8 & 64 & 623.5200 & 82.4327 \\
\hline $2016 / 17$ & 105.34 & 9 & 81 & 948.0600 & 88.3569 \\
\hline & $\sum \mathrm{y}=630.70$ & $\sum \mathrm{x}=9$ & $\sum \mathrm{x} 2=489$ & $\sum \mathrm{xy}=2896.9210$ & \\
\hline
\end{tabular}

Source: Economic Survey, 1999/00 to 2016/17

Here to identify the trend line, least square method of time series analysis has been used, as formula of trend line:

Where, $a=\frac{\sum y}{n}=\frac{630.70}{18}=35.0391 b=\frac{\sum x y}{\sum x^{2}}=\frac{2896.9210}{489}=5.9242$ 


\section{Appendix-iii}

\section{Calculation of correlation coefficient between VAT and total revenue (In Rs Billions)}

\begin{tabular}{|c|c|c|c|c|c|c|c|}
\hline FY & Total revenue $(\mathrm{x})$ & $\mathrm{dx}=\mathrm{x}-62.33$ & $\mathrm{dx}^{2}$ & Sales tax/VAT & $d y=y-14.47$ & $\mathrm{dy}^{2}$ & dx.dy \\
\hline $1991 / 92$ & 13.51 & -48.82 & 2383.39 & 2.84 & -11.63 & 135.26 & 567.78 \\
\hline $1992 / 93$ & 15.14 & -47.19 & 2226.90 & 3.43 & -11.04 & 121.88 & 520.98 \\
\hline 1993/94 & 19.58 & -42.75 & 1827.56 & 4.69 & -9.78 & 95.65 & 418.10 \\
\hline $1994 / 95$ & 24.61 & -37.72 & 1422.80 & 6.03 & -8.44 & 71.23 & 318.36 \\
\hline 1995/96 & 27.89 & -34.44 & 1186.11 & 6.43 & -8.04 & 64.64 & 276.90 \\
\hline 1996/97 & 30.37 & -31.96 & 1021.44 & 7.12 & -7.35 & 54.02 & 234.91 \\
\hline $1997 / 98$ & 32.93 & -29.4 & 864.36 & 7.12 & -7.35 & 54.02 & 216.09 \\
\hline 1998/99 & 37.25 & -25.08 & 629.01 & 8.76 & -5.71 & 32.60 & 143.21 \\
\hline 1999/00 & 42.89 & -19.44 & 377.91 & 10.25 & -4.22 & 17.81 & 82.04 \\
\hline $2000 / 01$ & 48.89 & -13.44 & 180.63 & 12.38 & -2.09 & 4.37 & 28.09 \\
\hline $2001 / 02$ & 50.44 & -11.89 & 141.37 & 12.26 & -2.21 & 4.88 & 26.28 \\
\hline $2002 / 03$ & 56.22 & -6.11 & 37.33 & 13.45 & -1.02 & 1.04 & 6.23 \\
\hline 2003/04 & 62.33 & 0 & 0.00 & 14.47 & 0 & 0.00 & 0.00 \\
\hline $2004 / 05$ & 70.12 & 7.79 & 60.68 & 18.88 & 4.41 & 19.45 & 34.35 \\
\hline $2005 / 06$ & 72.28 & 9.95 & 99.00 & 21.61 & 7.14 & 50.98 & 71.04 \\
\hline $2006 / 07$ & 87.71 & 25.38 & 644.14 & 26.09 & 11.62 & 135.02 & 294.92 \\
\hline $2007 / 08$ & 107.62 & 45.29 & 2051.18 & 29.81 & 15.34 & 235.32 & 694.75 \\
\hline $2008 / 09$ & 143.47 & 81.14 & 6583.70 & 39.7 & 25.23 & 636.55 & 2047.16 \\
\hline $2009 / 10$ & 177.98 & 115.65 & 13374.92 & 54.92 & 40.45 & 1636.20 & 4678.04 \\
\hline $2010 / 11$ & 201.01 & 138.68 & 19232.14 & 61.66 & 47.19 & 2226.90 & 6544.31 \\
\hline $2011 / 12$ & 244.14 & 181.81 & 33054.88 & 72.18 & 57.71 & 3330.44 & 10492.26 \\
\hline $2012 / 13$ & 296.01 & 233.68 & 54606.34 & 83.5 & 69.03 & 4765.14 & 16130.93 \\
\hline $2013 / 14$ & 356.62 & 294.29 & 86606.60 & 100.97 & 86.5 & 7482.25 & 25456.09 \\
\hline $2014 / 15$ & 405.86 & 343.53 & 118012.86 & 118.49 & 104.02 & 10820.16 & 35733.99 \\
\hline $2015 / 16$ & 481.96 & 419.63 & 176089.34 & 127.75 & 113.28 & 12832.36 & 47535.69 \\
\hline $2016 / 17$ & 609.18 & 546.85 & 299044.92 & 166.46 & 151.99 & 23100.96 & 83115.73 \\
\hline \multirow{2}{*}{ Total } & \multirow{2}{*}{$\sum x=3716.01$} & $\sum \mathrm{dx}=$ & $\sum \mathrm{dx}^{2=}$ & $\sum y=$ & $\sum \mathrm{dy}=$ & $\sum \mathrm{dy}^{2}=$ & $\sum \mathrm{dx} \cdot \mathrm{dy}=$ \\
\hline & & 2095.43 & 821759.54 & 1031.25 & 655.03 & 67929.15 & 235668.20 \\
\hline
\end{tabular}

Source: Economic Survey, 1991/ 92 to 2016/17

This table provides us following necessary calculations to find out correlation coefficient between VAT and total revenue.

As we know,

$$
\begin{aligned}
& r=\frac{N \cdot \sum d x \cdot d y-\sum d x \cdot \sum d y}{\sqrt{N \sum d x^{2}-\left(\sum d x\right)^{2}} \sqrt{N \sum d y^{2}-\left(\sum d y\right)^{2}}} \mathrm{r}=0.9980 \quad \mathrm{r}^{2}=0.9961 \text { Calculation of } \mathrm{PEr} \\
& \mathrm{PEr}=0.6745 \times \frac{1-r^{2}}{\sqrt{N}}=0.6745 \times \frac{1-(0.9961)}{\sqrt{26}}=0.000518 \mathrm{PEr}=0.0005186 \\
& \mathrm{PEr}=6^{*} 0.000518=0.00
\end{aligned}
$$




\section{Appendix-iv}

Correlation Coefficient between VAT and Total Tax Revenue (In Rs Billions)

\begin{tabular}{|c|c|c|c|c|c|c|c|}
\hline Years & $\begin{array}{c}\text { Total tax } \\
\text { revenue }(\mathrm{x})\end{array}$ & $d x=x-48.17$ & $d x^{2}$ & Sales tax/VAT & $d y=y-14.47$ & $\mathrm{Dy}^{2}$ & dx.dy \\
\hline 1991/92 & 9.87 & -38.30 & 1466.89 & 2.84 & -11.63 & 135.26 & 445.43 \\
\hline 1992/93 & 11.66 & -36.51 & 1332.98 & 3.43 & -11.04 & 121.88 & 403.07 \\
\hline 1993/94 & 15.36 & -32.81 & 1076.50 & 4.69 & -9.78 & 95.65 & 320.88 \\
\hline 1994/95 & 18.94 & -29.23 & 854.39 & 6.03 & -8.44 & 71.23 & 246.70 \\
\hline 1995/96 & 21.66 & -26.51 & 702.78 & 6.43 & -8.04 & 64.64 & 213.14 \\
\hline 1996/97 & 24.42 & -23.75 & 564.06 & 7.12 & -7.35 & 54.02 & 174.56 \\
\hline 1997/98 & 25.93 & -22.24 & 494.62 & 7.12 & -7.35 & 54.02 & 163.46 \\
\hline 1998/99 & 28.38 & -19.79 & 391.64 & 8.76 & -5.71 & 32.60 & 113.00 \\
\hline 1999/00 & 33.15 & -15.02 & 225.60 & 10.25 & -4.22 & 17.81 & 63.38 \\
\hline $2000 / 01$ & 38.86 & -9.31 & 86.68 & 12.38 & -2.09 & 4.37 & 19.46 \\
\hline $2001 / 02$ & 39.33 & -8.84 & 78.15 & 12.26 & -2.21 & 4.88 & 19.54 \\
\hline $2002 / 03$ & 42.58 & -5.59 & 31.25 & 13.45 & -1.02 & 1.04 & 5.70 \\
\hline $2003 / 04$ & 48.17 & 0.00 & 0.00 & 14.47 & 0 & 0.00 & 0.00 \\
\hline $2004 / 05$ & 54.10 & 5.93 & 35.16 & 18.88 & 4.41 & 19.45 & 26.15 \\
\hline $2005 / 06$ & 57.43 & 9.26 & 85.75 & 21.61 & 7.14 & 50.98 & 66.12 \\
\hline $2006 / 07$ & 70.10 & 21.93 & 480.92 & 26.09 & 11.62 & 135.02 & 254.83 \\
\hline $2007 / 08$ & 85.15 & 36.98 & 1367.52 & 29.81 & 15.34 & 235.32 & 567.27 \\
\hline $2008 / 09$ & 117.05 & 68.88 & 4744.45 & 39.7 & 25.23 & 636.55 & 1737.84 \\
\hline $2009 / 10$ & 156.20 & 108.03 & 11670.48 & 54.92 & 40.45 & 1636.20 & 4369.81 \\
\hline $2010 / 11$ & 171.83 & 123.66 & 15291.80 & 61.66 & 47.19 & 2226.90 & 5835.52 \\
\hline $2011 / 12$ & 206.36 & 158.19 & 25024.08 & 72.18 & 57.71 & 3330.44 & 9129.14 \\
\hline $2012 / 13$ & 259.62 & 211.45 & 44711.10 & 83.5 & 69.03 & 4765.14 & 14596.39 \\
\hline $2013 / 14$ & 312.44 & 264.27 & 69838.63 & 100.97 & 86.5 & 7482.25 & 22859.36 \\
\hline $2014 / 15$ & 355.96 & 307.79 & 94734.68 & 118.49 & 104.02 & 10820.16 & 32016.32 \\
\hline $2015 / 16$ & 421.09 & 372.92 & 139069.33 & 127.75 & 113.28 & 12832.36 & 42244.38 \\
\hline $2016 / 17$ & 547.48 & 499.31 & 249310.48 & 166.46 & 151.99 & 23100.96 & 75890.13 \\
\hline & $\sum x=3173.12$ & $\sum \mathrm{dx}=1920.70$ & $\begin{array}{l}\sum \mathrm{dx} 2= \\
663669.92\end{array}$ & $\sum y=1031.25$ & $\sum \mathrm{dy}=655.03$ & $\sum$ dy $2=67929.15$ & $\begin{array}{l}\sum \mathrm{dx} . \mathrm{dy}= \\
211781.58\end{array}$ \\
\hline
\end{tabular}

Source: Economic Survey, 1991/ 92 to 2016/17

This table provides us following necessary calculations to find out correlation coefficient between VAT and total tax revenue.

As we know,

$$
\begin{gathered}
r=\frac{N \cdot \sum d x \cdot d y-\sum d x \cdot \sum d y}{\sqrt{N \sum d x^{2}-\left(\sum d x\right)^{2} \sqrt{N \sum d y^{2}-\left(\sum d y\right)^{2}}} \mathrm{r}=0.9974 \mathrm{r}^{2=} 0.9949 \text { Calculation of PEr }} \\
\mathrm{PEr}=0.6745 \times \frac{1-r^{2}}{\sqrt{N}}=0.6745 \times \frac{1-(0.9949)}{\sqrt{26}}=0.0006726 \mathrm{PEr}=0.004032
\end{gathered}
$$

